\title{
T-Rex in Wonderland: Kentucky's 27-million-dollar Creation Museum Turns One
}

\author{
Gordy Slack
}

Published online: 19 June 2008

(C) Springer Science + Business Media, LLC 2007

"With all her knowledge of history, Alice had no very clear notion how long ago anything had happened."Lewis Carroll, Alice in Wonderland

One year ago, when I covered the opening of the Answers in Genesis Creation Museum in Petersburg, Kentucky (Slack 2007), I asked preacher Ken Ham, Answers in Genesis' rugged-faced CEO and president, why the age of the Earth matters so much to his followers. "If any word of the Bible is false," he said, "then all of it can be called into question."1 From Ham's point of view, the authority of the entire Bible rides on every word in it. If Genesis is wrong, then the Ten Commandments might as well be, too. And it is the Ten Commandments and other moral pronouncements in the Bible that are important to Ham, not really, in themselves, the age of the Earth or the method by which it was populated. The real concern and target of creationism is not evolution, it is moral relativism.

The Creation Museum is no little roadside attraction. It's a polished, 27-million-dollar, 60,000-square-foot "natural history" museum just about 20 miles southwest of Cincinnati and within easy driving distance of millions of people. In the 12 months since its opening, according to the museum's website, more than 360,000 people have visited its halls. Answers in Genesis (AiG), the nonprofit ministry devoted to what it calls Biblical apologetics, or "the reasoned defense of the Bible," is projecting at least as many in the year to come.

It is remarkable that $\mathrm{AiG}$ was able to raise nearly 30 million dollars to build the museum and fill it with exhibits,

\section{G. Slack $(\bowtie)$}

Slack Ink,

405 14th Street, Suite 1207,

Oakland, CA 94618, USA

e-mail: g.slack@gmail.com but more astounding still is the fact that so many Americans will come here and say, "Finally, a decent science museum for me!" In fact, I heard that sentiment repeated time and again from museum visitors. A 2007 Newsweek poll found that $48 \%$ of Americans hold that "God created humans pretty much in the present form at one time within the last 10,000 years or so." (Newsweek Poll 2007). That means about half of Americans would feel perfectly at home at the Creation Museum. That's a higher percentage than accept the view of the world portrayed in mainstream science museums. In the same poll, only $43 \%$ answered affirmatively to the assertion that "Humans developed over millions of years from less advanced forms of life."

Ham is explicit about the museum's purpose. He hoped, he said, that it would undo "the damage done 82 years ago when Clarence Darrow put William Jennings Bryan on the stand" in the famous Scopes trial in Dayton, Tennessee. "Bryan was asked questions about the Book of Genesis that he couldn't answer," said Ham. "It was the first time the Bible was ridiculed by the media in America, and that was a downward turning point for Christendom." In the decades that followed, Ham said, the Bible's values were replaced by a tolerance for homosexuality, divorce, sexual promiscuity, porn, and the banning of God from schools and courts.

"We are going to undo all of that here at the Creation Museum," said Ham. "We are going to answer the questions Bryan wasn't prepared to, and show that belief in every word of the Bible can be defended by modern science."

I am an evolutionist, not religious, and not an advocate of creationism in any of its forms. But wherever you stand on the evolution-creation debate, this museum has a lot to

\footnotetext{
${ }^{1}$ This and all other quotes from Ken Ham were obtained in personal interviews that I conducted with him at the museum in Petersburg on May 29-30, 2007.
} 
teach you. It is probably the clearest expression of the creationist worldview on Earth. Despite the rise of new and more complex sub-species of creationism, such as intelligent design, young-earthism is creationism's holotype, the original and essential specimen. Anyone hoping to understand the majority of Americans who reject evolution for a Biblical view should take a hard look at this place.

Early in the twentieth century, science didn't enjoy the same status it does today in American culture. In the 1925 Scopes Trial over the teaching of evolution in Tennessee public schools, for instance, the judge didn't even permit scientific testimony into the court record. It was as if it didn't really matter whether the conclusions of science were incompatible with a literal Biblical account of things (Larson 1997).

But science and technology have come too far, become too integral to the American identity, to be ignored or dismissed today. Today's young-earth creationists have to at least acknowledge the validity of science as a way of accessing the truth and the powers such access grants us. Once they recognize the authority of science, though, young-earth creationists must then argue, against libraries and labs and museum collections full of evidence, that it substantiates their essentially unscientific claims.

There is no need to deconstruct the message embedded in the Creationist Museum, it is right up front. Ken Ham told me that every word of the Bible is literally true. Not just "resonant" or "relevant" or "metaphorical," but true. True like the second law of thermodynamics, like $1+1=2$, like the Earth spinning on its axis and circling the sun.

Trying to squeeze billions of years of evolutionary history into 6 days of creation, to contradict the voluminous and unequivocal evidence supporting common descent and the creative potency of natural selection, and to apologize for a scenario completely at odds with what the evidence suggests, is one tough assignment. This museum represents the young-earth community's best effort to fulfill it.

The museum is beautifully built out of carefully chosen and expensive materials. The exhibits are well designed and artistically executed. And from a little distance they look familiar; dinosaur skeletons, soaring pterosaurs, live tropical frogs, a diorama of an archeological site, and primordial forests occupied by animatronic dinosaurs. But take a step closer and you may feel the queasy vertigo I did upon seeing humans stuck in among the T-rexes and velociraptors.

The museum's exhibits explain that an all-powerful God made the universe, the Earth and everything on it, including Adam and Eve, whom he put here so they could worship Him. Everything was perfect, until Adam and Eve ate fruit from the Tree of Knowledge. Enlightenment marked the downturn not only for the first family, but for the entire universe. It spoiled everything. No wonder Biblical literalists are hostile toward science! Knowledge, the whole point of science, was a product peddled by Satan, and the most potent poison around. Everything that has happened since - mortality, the invention of carnivory, the Great Flood, God's sending his son Jesus to be tortured and killed, all the suffering and hardship experienced by billions of human and other creatures - all of it was set in motion by Adam's and Eve's choice of knowledge over ignorance, according to this view.

It would be a waste of my time and yours to look critically at each assertion the museum's curators and designers make about the origins of life, natural selection, geology, dating methods, fossilization, speciation, and astronomy. I think Ken Ham would concur that the evolution-creationism debate is not essentially a disagreement over the facts (though it is that, too), or even the interpretation of the facts, as much as it is a disagreement about what makes a fact a fact, and most importantly, what kind of a world facts and theories belong to. Refutations of the museum's individual claims, however, are easy to find. My favorite books on the subject are Eugenie Scott's Evolution vs. Creationism: An Introduction, (Scott 2004) and Niles Eldredge's The Triumph of Evolution and the Failure of Creationism. (Eldredge 2000) The Talk Origins website (http://www.talkorigins.org/) also has a good list.

The museum is laid out according to what its designers call "The Seven C's of History: Creation, Corruption, Catastrophe, Confusion, Christ, and the final C, Consummation," which refers to the apocalypse. First, there's Creation. After a Big-Bang-like creation event and 5 days of setting the stage, on the sixth day, God made all the animals and Adam and Eve. Just inside the museum's entrance wait two young T. rexes, peacefully watching fish swim in a placid pond while two hapless, curly-haired robotic kids play nearby. In this pre-Noah's-flood diorama, Jurassic Park is still benign, all animals are vegetarians here, and plants don't yet have a need for thorns.

"They all had to exist at the same time, because they were all made on the same day," Mark Looy, co-founder of AiG, told me matter-of-factly as we toured the museum the day before the opening. "There isn't any fossil evidence showing them [dinosaurs and people] in the same place at the same time, that part is just speculation," he says. "But it is clearly written that they were alive at the same time."

The universe, the museum explains, is 6,000 years old and all of the basic forms of life we see today were brought into being at once on the sixth day. While some micromutations have occurred, and many extinctions have, no new "types" have been introduced since those first days. Evolution, the museum tells us, is a dangerous myth.

There are several reasons why evolution is particularly threatening to creationists, especially young-earthers. (1) If 
evolution if was driven by natural selection working on random genetic mutations, the world must be very oldand thus the literal interpretation of the Bible must be wrong-because it takes natural selection a very long time to do its thing, (2) evolution explains how the diversity of life we see on Earth today might have arisen even without the intervention a God, i.e., it arguably makes God superfluous, (3) if humans are animals, like other primates, we don't necessarily have any special, privileged place in the world. Our acquisition of knowledge is an evolutionary adaptation, not a moral choice; and if knowledge came to us without choice, then how can we be blamed? And finally, (4) evolution is a brutal process, "red in tooth and claw." And it always was. If paradise never existed, then why would Jesus need to die in order to restore it? And, anyway, why would a just and loving God choose such a brutal method of creating the diversity of life when He could presumably have taken a kinder, gentler route?

Like evolution, geology is a sensitive subject for youngearth creationists. The museum's geology exhibit tells us that the Great Flood, which God brought down on the Earth 4,350 years ago, is responsible for the fossil record. The distribution of fossils in different geologic strata is based not on the fossils' age, but on where the floodwaters moved them before receding. Those areas where no thorns or other defensive or hostile plants are found are pre-flood forms. And see, the pre-flood forms have no thorns, which proves the existence of Eden! If the reasoning sounds circular, that's okay, Ham said, because every argument has to have a bias, a premise underlying it, and his bias, Ham told me, is the Truth of the Word of God, which is much more reliable than the Fickle Reason of Man.

Further along in the museum, the designers get to their real business in an exhibit that tries to link belief in Darwin, and the falling off of belief in Genesis, to the rise of homosexuality, abortion, drug use, urban decay, and even the Third Reich and the atrocities of Pol Pot and Stalin; in this view, totalitarianism is the ultimate political expression of social Darwinism.

In the Creation Museum's Garden of Eden exhibit, no animals are yet predators or prey, so the museum's designer, Patrick Marsh, could crowd wildcats, zebra-like animals, kangaroos, grizzly bears, an iguanodon, and several other dinosaurs, all into the same little chunk of primeval real estate. To an evolutionist's eye, the effect is, frankly, goofy, like Abe Lincoln dressed in a tie-dyed shirt and bell-bottoms.

A little farther along a bearded, finely muscled, darkhaired Adam has one arm wrapped around a little lamb while he beckons to a mountain lion with the other. God's first assignment for Adam was to name all the animals and he looks a little overwhelmed by the job; there were many more "kinds" in those days even than there are today.
That's a lot of names to come up with. And Latin nomenclature wasn't going to be invented for 2,000 years.

A bit further along we're introduced to Eve, who's being made from one of Adam's ribs. Actually, she's just sitting there next to him; and the whole rib Zip-file extraction process is left to our imaginations (now that would have been a cool special effects application), but there she is, looking like a great big Brown Barbie and staring perhaps just a little too intently into Adam's eyes. They are naked, naturally, since the Fall hasn't happened yet. It seems unfair of God to expect two such well-designed specimens not to get around to sinning pretty quickly.

A few yards further down the trail of life we see Adam and Eve again, this time standing in a pool of water, their genitals, of which they are not yet ashamed, just barely obscured by lily pads. At this point, they are clearly grappling with the serious chemistry that will soon get them in big trouble.

An over-sized cobra-like snake, representing Satan, makes an appearance and before you know it, there Eve is holding little blood-colored wild-grape-sized fruits in her outstretched hand, offering knowledge of good and evil to a befuddled Adam. The fruit wasn't an apple, the museum explains, though it's not clear yet what it was. (Now that is a subject for some young paleobotany grad student's dissertation.) Maybe the fruits were grapes; a little vino goes a long way to pave the path to sin.

We all know what happens next; Eve gets Adam to taste knowledge of good and evil, they become ashamed of their nakedness and hide in the bushes from God, who, being omnipresent, is everywhere except, I guess, in the bushes.

After Adam's and Eve's initial sin, humans just get creepier and creepier and things spiral downward. Tiring of all the lies and weakness of will, God tells Noah to build an Ark and sends him two of each kind of land animal on Earth with which to repopulate the world once God had drowned everyone else. That big flood, the exhibit says, explains not only where scientists find fossils today but also the topography of the modern world. The Grand Canyon, for instance, was cut in a very short time as the waters of the flood rushed away and the land was reclaimed.

In the Ark exhibit, Noah and his building crew are shown constructing a supposedly full-scale section of the boat. (The real Ark, we are told, was $510 \mathrm{ft}$ long and $51 \mathrm{ft}$ tall.) The exhibit has a chilling effect when, after Noah has invited his sinning neighbors onto the Ark and warned them of the coming flood, they ignore him or are dissuaded from heeding his advice by the small pressures of daily life. The door slides shut and they are left behind to drown in the 40day deluge that formed everything we see on Earth today from Mt. Everest to Death Valley. Now that's tough love.

After God drowns everyone on Earth but Noah's family, they multiply again, but not quickly or broadly enough to satisfy God, who then introduces new languages, resulting 
in the dispersal of people around the globe. This is the " $\mathrm{C}$ " for "Confusion." The exhibit represents this period with an urban back-alley plastered with graffiti about homosexuality, abortion, and teen suicide. In the middle of this urban mess is a big wrecking ball with the words "millions of years" carved into it. Take out Darwinism and "millions of years," restore faith in the Word, and, the exhibit suggests, we might make our way back to pre-1925 Dayton, Tennessee.

Which reminds me of what Lewis Carroll's Alice replied when the Duchess told her to mind her own business so the world could "go around a great deal faster than it does."

“"Which would not be an advantage,' said Alice, who felt very glad to get an opportunity of showing off a little of her knowledge. 'Just think of what work it would make with the day and night! You see the earth takes twenty-four hours to turn round on its axis-'
'Talking of axes,' said the Duchess, 'chop off her head!"” Carroll (2001)

\section{References}

Carroll L. Alice in Wonderland. New York: Courier Dover; 2001. p. 46.

Eldredge N. The triumph of evolution and the failure of creationism. New York: Freeman; 2000.

Larson EJ. Summer for the Gods: the scopes trial and America's continuing debate over science and religion. New York: BasicBooks; 1997.

Newsweek Poll conducted by Princeton Survey Research Associates International. March 28-29, 2007. $N=1,004$ adults nationwide; 2007.

Scott E. Evolution vs. creationism: an introduction. 1st ed. Berkeley: University of California Press; 2004.

Slack G. Inside the creation museum. Salon.com May 31, 2007; 2007. 